June 1993

\title{
TRANSPORTATION AS A MEANS OF INCREASING WILD JUVENILE SALMON SURVIVAL Recovery Issues for Threatened and Endangered Snake River Salmon
}

Recovery Issues for Threatened and Endangered Snake River Salmon Technical Report 4 of 11

Technical Report 1993

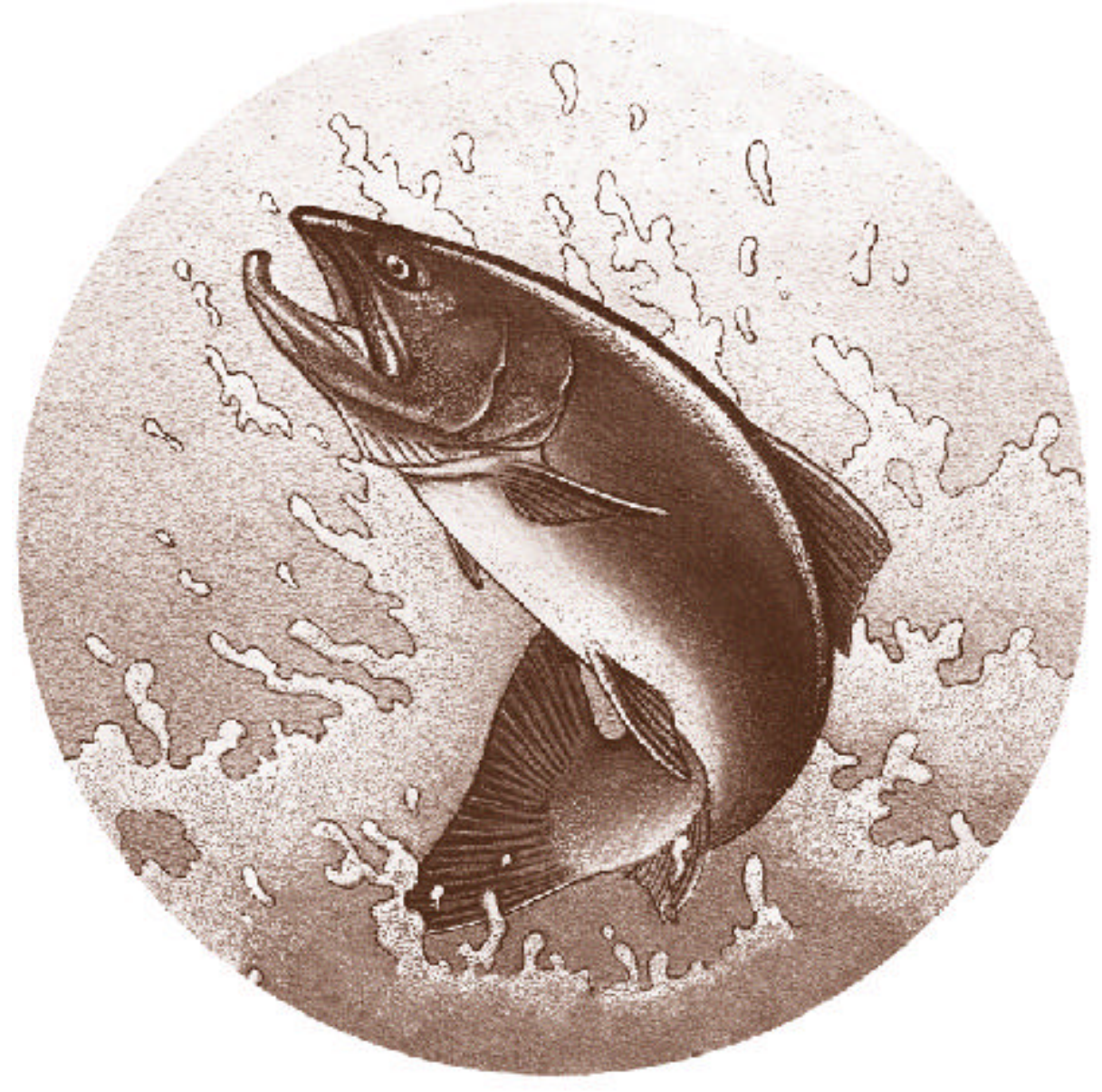

DOE/BP-99654-4 
This report was funded by the Bonneville Power Administration (BPA), U.S. Department of Energy, as part of BPA's program to protect, mitigate, and enhance fish and wildlife affected by the development and operation of hydroelectric facilities on the Columbia River and its tributaries. The views of this report are the author's and do $r$ necessarily represent the views of BPA.

This document should be cited as follows:

Park, D.L.; S.P. Cramer \& Associates, Inc., U.S. Department of Energy, Bonneville Power Administration, Division of Fish and Wildlife, Project No. 93-013, Contract No. DE-AM79-93BP99654, 45 electronic pages (BPA Report

DOE/BP-99654-4)

This report and other BPA Fish and Wildlife Publications are available on the Internet at:

\section{http://www.efw.bpa.gov/cgi-bin/efw/FW/publications.cgi}

For other information on electronic documents or other printed media, contact or write to:

Bonneville Power Administration

Environment, Fish and Wildlife Division

P.O. Box 3621

905 N.E. 11th Avenue

Portland, OR 97208-3621

Please include title, author, and DOE/BP number in the request. 
This report was funded by the Bonneville Power Administration (BPA), U.S. Department of Energy, as part of BPA's program to protect, mitigate, and enhance fish and wildlife affected by the development and operation of hydroelectric facilities on the Columbia River and its tributaries. The views in this report are the author's and do not necessarily represent the views of BPA.

For additional copies of this report, write to:

Bonneville Power Administration

Public Information Office - ALP-22

P.O. Box 3621

Portland, OR 97208

Please include title, author, and DOE/BP number from back cover in the request. 


\title{
TRANSPORTATION AS A MEANS OF INCREASING WILD JUVENILE SALMON SURVIVAL
}

\section{Recovery Issues for Threatened and Endangered Snake River Salmon Technical Report 4 of 11}

\author{
Prepared by \\ D. L. Park1 \\ under subcontract to \\ S.P. Cramer \& Associates, Inc. \\ Gresham, OR \\ Prepared for \\ U.S. Department of Energy \\ Bonneville Power Administration \\ Division of Fish and Wildlife \\ P.O. Box 3621 \\ Portland, OR 972083621 \\ Project No. 93-013 \\ Contract No.DE-AM79-93BP99654
}

June 1993

1 Don Chapman Consultants, Inc., Boise, ID 


\section{TABLE OF CONTENTS}

EXECUTIVE SUMMARY i

1. INTRODUCTION

1.1 ACKNOWLEDGEMENTS

2. FACTORS INFLUENCING TRANSPORTATION STUDY RESULTS

2.1. POPULATION STRUCTURE CHANGES

2.2. CHANGES IN THE HYDRO SYSTEM 4

2.3. IMPROVEMENTS TO JUVENILE FISH PASSAGE FACILITIES 5

2.4. DEBRIS REMOVAL, FISH HANDLING, AND OTHER IMPROVEMENTS

2.5. NATURAL.EVENTS

3. SUMMARY RESULTS OF SMOLT TRANSPORTATION EXPERIMENTS 1968 TO 1992

3.1. SPRING/SUMMER CHINOOK SALMON

3.2. SOCKEYE SALMON -PRIEST RAPIDS DAM

3.3. FALL CHINOOK SALMON

4. INTERPRETATION OF TRANSPORT RESULTS 16

4.1. SPRING/SUMMER CHINOOK SALMON 16

4.2. SOCKEYE SALMON

4.3. FALL CHINOOK SALMON

5. EFFECT OF TRANSPORTATION ON HOMING 18

6. POINT-OF-ORIGIN TRANSPORTATION STUDIES 19

7. DISEASE IN TRANSPORTED FISH AND TRANSPORT SYSTEMS $\quad 20$

8. TRANSPORTATION BENEFITS FOR WILD FISHH 22

9. MODELING SMOLT TRANSPORTATION BENEFITS 23

10. TRANSPORTATION: AN ALTERNATIVE TO SCREEN ANDBYPASS 24

11. AN ANALYSIS OF TRANSPORTATION AS AN ALTERNATIVE TO "SPREAD THE RISK" 
12. FUTURE TRANSPORTATION OPTIONS 27

12.1. TRANSPORT MODE 27

12.2. MIXED-SPECIES TRANSPORT 27

12.3. LOADING DENSITIES 27

13. RESEARCH FOR ENHANCING WILD FISH 28

13.1. RELEASE SITE STUDIES 28

13.2. HOMING STUDIES 28

13.3. HATCHERY FISH FOR RESEARCH 29

14. LITERATURE CITED 30 


\section{EXECUTIVE SUMMARY}

Smolt transportation on the Snake and Columbia Rivers has been under nearly continuous study for 25 years. Though all of the listed species have been studied in past years, only spring/summer chinook salmon (Oncorhvnchus tshawytscha) were researched intensively from 1968 to 1989 at Snake River dams. Sockeye salmon (0. nerka) were studied at Priest Rapids Dam 1984 to 1989 and those data may be applied to some degree in the Snake River. Fall chinook (Q. fshawvtscha) were studied at McNary Dam 1978 to 1983 and 1986 to 1988 . Adult evaluations continue from the most recent studies.

Most controversy surrounds transport of spring/summer chinook, so most analyses and discussion are devoted to that species. Sockeye migrate at the same time as spring/summer chinook as do the earliest of the fall chinook. Therefore, action taken on spring/summer chinook will also affect sockeye and fall chinook.

Many factors influenced transportation study results over the years. These include: 1) population structure change--the shift from nearly all wild fish to nearly all hatchery fish; 2) new dams--John Day 1968, Lower Monumental 1969, Little Goose 1970, and Lower Granite 1975; 3) the number of turbines at Snake River dams alone increased from 3 in 1968 to 24 by 1979; 4) installation of juvenile fish pass facilities; and 5)

calamitous natural events such as the 1977 drought. All the above had negative effects on the survival of wild fish in general and on transport test results specifically, except that when smolts were transported from the upper dam their survival was not influenced by new or existing structures downstream from the transport site.

The most important change affecting transport studies was the shift in population structure. In 1968, 1,460,000 fish were released from hatcheries--in 1992 the number of spring/summer chinook had reached $11,025,000$. At first, hatchery fish survived nearly as well as wild fish but a general breakdown occurred in the early 1970s. Through the subsequent years survival of hatchery fish continued to decline. The low survival of hatchery fish the last two decades has been attributed to bacterial kidney disease (BKD). The primary reason transport results became inconclusive is that wild fish numbers declined as a percent of the smolt population, while at the same time hatchery fish increased. Since transport experiments were designed with survivability of wild fish in mind, by the late 1970 s too few fish were marked to compensate for the low rate of return of hatchery fish that had come to predominate the smolt population. I conclude that smolt quality of hatchery-reared spring/summer chinook influenced transportation results and is now a factor more limiting to their survival than passage through dams.

A few changes or events have increased smolt survival. Among these have been improvements in screen/bypass systems, exceptionally good water years such as 1975, and good ocean survival years such as 1982 to 1985 . These increased the rate of return of transported and non-transported fish alike.

Entrained debris, a killer in collection systems at dams, was under control at Lower Granite Dam by 1982. At about the same time a "pre-anesthesia" system for fish handling was initiated by the National Marine Fisheries Service. These actions reduced marking/handling mortality and presumably increased the rate of adult return of 
transportation test fish.

Spring/summer chinook were marked for transport tests at Ice Harbor Dam during 1968 to 1970. In 1971, tests began at Little Goose Dam and continued through 1978 (except 1974-75). When Lower Granite Dam was completed in 1975, tests began and continued through 1980. In 1986 a series of re-evaluation tests began and in 1989 a second year of that study was completed. At McNary Dam, tests were conducted from 1978 to 1980 and a second series completed from 1986 to 1988. Trucks were used at all sites exclusively to 1977 . Then, barges were introduced and by 1983 trucks were no longer used in transport tests. Tests using trucks were conducted at Priest Rapids Dam from 1984 to 1986.

Sockeye salmon have not been studied on the Snake River. However, tests were conducted at Priest Rapids Dam on the Columbia River from 1984 to 1988. Summary data are presented but no final report has been issued for the Priest Rapids study.

Fall chinook salmon were studied at McNary Dam in 1978 to 1983. They were re-evaluated in 1986 to 1988 .

Examination of the data reveals that 29 separate studies on Snake River spring/summer chinook were completed over 25 years. Of these, 13 had statistically significant more transported fish return than control fish. In eight tests there were no significant difference among test groups, too few returns occurred for analysis in seven tests and, in one test, significantly more controls returned than did transported fish. In tests conducted from 1968 to 1975 , wild fish were abundant among those marked for experiments. The rate of return of transported fish in 1968 was about 40 times that observed in most recent studies. Because hatchery fish have predominated the smolt outmigration since the. mid-1970's, and their rate of return is low, the earlier data should be used for assessing transport benefits for listed species. The transport data suggest that wild fish have received much more benefit from transportation than the hatchery component. This was confirmed in steelhead tests where the rate of return of wild fish was double that of hatchery fish. I conclude that transportation should be used for protecting spring/summer chinook through a full range of river flow and powerhouse operating conditions.

Sockeye salmon tests at Priest Rapids Dam were inconclusive. There is a fear that those experiments were compromised by inadequate fish release procedures and/or poor release locations. Since Snake River sockeye migrate in concert with spring/summer chinook, (and there is no compelling evidence that they should not be transported), the sockeye should be transported with chinook. If sockeye are restudied on the mid-Columbia River, those results may be useful for long range transport decisions on the Snake River.

Fall chinook were studied eight years (nine tests) at McNary Dam. The transport benefit ratio (TBR) ranged from 2:1 to 7:1 and all tests were statistically significant. As with the other species, fall chinook salmon should be transported.

Loss of homing in very few adult spring/summer chinook and sockeye has been documented. This was evidenced by strays or wanderers into the Deschutes River, Oregon. Eleven chinook from the Snake River; and four chinook and 2 sockeye from the mid-Columbia River were found there (about 2,000 transported fish were observed 
returning to the respective dams of origin). Other evidence of straying has been rare with no straying reported for fall chinook salmon. The principal investigators of transportation agree that homing loss is not a serious problem.

Various investigators have experimented with the concept of transporting salmon from hatcheries direct to the lower Columbia River or near ocean release sites (point-oforigin). Survival of smolts was sometimes increased dramatically while homing loss in returning adults was severe. In future experiments it may be practical to adjust designs so that homing could be achieved at acceptable levels.

Disease in fish transported or in transportation systems was unknown in 1968. Now, however, BKD is rampant and virtually all salmonids, including listed spring/summer chinook in the Snake and Columbia Rivers, carry the disease.

The disease organism was successfully cultured from the transportation barge circulation system during 1990. The disease was also documented to have been transmitted horizontally (from fish to fish in "sentinel" tests using Eastern brook trout) in the transport barge. In water samples. taken at Lower Granite, Priest Rapids, McNary, and Bonneville Dams (upstream face), presumptive presence of the bacterium was identified by fluorescent antibody technique (FAT). This suggests that the bacterium is universally present throughout the river system when smolts are transported. Since infection of the disease is more severe (as opposed to prevalent) among hatchery fish and presumably is shed mostly by those fish severely infected, it appears there is only one immediately practical solution to the problem; reduction in the number of hatchery fish released to the river. There are about 10 times more fish released now than 25 years ago. Reducing the number of hatchery fish would not only reduce the number of bacteria shed, but reduce the possibility of non-diseased listed species receiving the disease.

Bacterial kidney disease is extremely pervasive in the river system, yet it appears there is little risk in transporting listed species since many wild fish already carry the disease at low infection levels. Transportation should proceed coincidently with efforts to control BKD.

An analysis is presented for determining the transport benefit of wild spring chinook salmon using data from 1975 (Lower Granite Dam) when most fish marked were estimated to be wild. That year was also a good flow year when survival of inriver migrants was believed to be high. In my estimates, I projected that full transportation was used with a range of fish guidance efficiencies (FGE) from $10 \%$ to $70 \%$. About 50\% FGE is currently realized. Actual adult return estimates in 1975 are from Raymond (1988). Using the average TBR for the year (2.14:1), I estimated that the benefit in adults returned from transportation would have ranged from about 7,000 fish (10\% FGE) to 50,000 fish (70\% FGE).

Modeling transportation benefits for the Snake and Columbia rivers has been hampered by lack of test data for collector dams other than Lower Granite Dam. Some assumptions are invalid, such as, "once the fish are in the barge their survival to adult return is not dependent on factors that affect the survival of non-transported fish." BKD affects fish transported by barge the same as those migrating on their own; many, if not most of the infected fish, will die upon ocean entry. Another very serious deficiency of 
modeling is the projection of unrealistic low mortality of fish passing through bypass systems (2\%). Recent studies at Bonneville Dam show that mortality in bypasses at that dam is at least as great as turbine mortality. I conclude that present models of transportation are inappropriately applied.

Screen bypass systems are complete or will be soon at all dams from Lower Granite to Bonneville. The systems were originally conceived as collector points from which to transport smolts. None has been sufficiently evaluated as safe systems for passage of fish to the river. Consideration should be given to a return to the original plan for bypass systems. That is, that they should be used to collect for transport. Where extended bar screens are planned, extreme care should be taken to provide complete evaluation prior to implementation.

The "spread the risk" policy of bypassing a portion of the smolts collected at transportation facilities (dams) is not based on scientific data. The risk is too great for listed species to subject them to further rigors of downstream passage that include both known and unknown dangers of bypass systems. Tied to the policy is the unstated dictum (and an incorrect assumption) that transportation works only in low flow years. My analysis for 1975 shows there is a dramatic gain to be realized when smolts are transported during high flow years (TBR was 2.14: 1 but rate of return was high).

In future transport operations, listed fish should be hauled by barge. Safety factors override economic considerations. Small fish should be separated from large fish (steelhead) and transported in separate barge compartments. Present loading density of $0.50 \mathrm{lb}$ per gallon is probably adequate. However, if present density is determined to be a risk factor, reducing the number of steelhead (and chinook) released from hatcheries would eliminate fear of exceeding density criteria at collector sites.

Improving release sites holds much promise for enriching transport benefits. Some of these studies are currently underway using steelhead as test fish. Point-of-origin studies have indicated where improved release sites might be located (e.g., near Tongue Point) .

In conjunction with new lower river release sites, homing studies will probably be required. Availability of PIT tags and extended range monitoring for adults may assist in determining homing assessments. Hopefully, this can be accomplished using hatchery fish in place of wild fish.

Hatchery fish should be set aside for experimentation on transportation and other projects. Production releases such as occurred in the last decade have not been effective in returning adults to the Snake River. Present production levels are likely harmful and counterproductive to recovery goals for listed wild fish. 


\section{TRANSPORTATIONAS A MEANS OF INCREASING WILD JUVENILE SALMON SURVIVAL}

\section{INTRODUCTION}

Few research topics have been studied more intensively and been subjected to as much controversy as has the issue of smolt transportation. Transportation has been studied for 25 years, and still argument persists over interpretation of results. Underlying the controversy is a feeling on the part of some that transportation is unnatural, and that smolts should have the opportunity to swim to the ocean unassisted.

One example of an initially-challenged concept was homing. At the time transport experiments began at Ice Harbor Dam (Figure 1) in 1968, it was widely believed that the homing instinct would be destroyed if smolts were intercepted at Ice Harbor Dam and transported to below Bonneville Dam. However, Ebel (1973) correctly hypothesized that 'if smolts had the experience of migrating several hundred miles prior to interception at a dam, and were transported in water that contained traces of their home stream (i.e., fish from the Middle Fork of the Salmon River would be transported in Snake River water that has Middle Fork water as one of its components), smolts could be removed from the Snake River and placed back to the Columbia River with little or no homing loss.

Transportation research on the Snake River has continued since 1968. It began at Ice Harbor Dam, then moved upstream to Little Goose Dam in 1971 and finally to Lower Granite Dam in 1975. Later, studies were conducted at McNary and Priest Rapids Dams on the Columbia River in 1978 and 1984, respectively. Transportation research continues at Lower Granite and McNary Dams and final evaluation of the Priest Rapids Dam study has not been reported.

The National Marine Fisheries Service (NMFS) has defined the species considered for listing as the wild populations of naturally spawning salmon in the Snake River (Waples 1991). Therefore, where practical to do so, data from wild fish are used in the analyses. However, the reader must take into consideration that sockeye salmon at Priest Rapids Dam is the only stock consisting wholly of wild fish tested in the Columbia River system.

This report reviews transportation activity for Snake River spring/summer chinook, fall chinook, and sockeye salmon. Discussion of fall chinook salmon tests will be brief because I believe there is no longer controversy in management ranks regarding their transportation. Fall chinook data are from McNary Dam, where most test fish were of Columbia River origin. Most space is devoted to discussion of spring/summer chinook salmon because most controversy surrounds this species. Discussion of spring/summer chinook will apply to sockeye salmon, except where I specify midColumbia River sockeye salmon. 


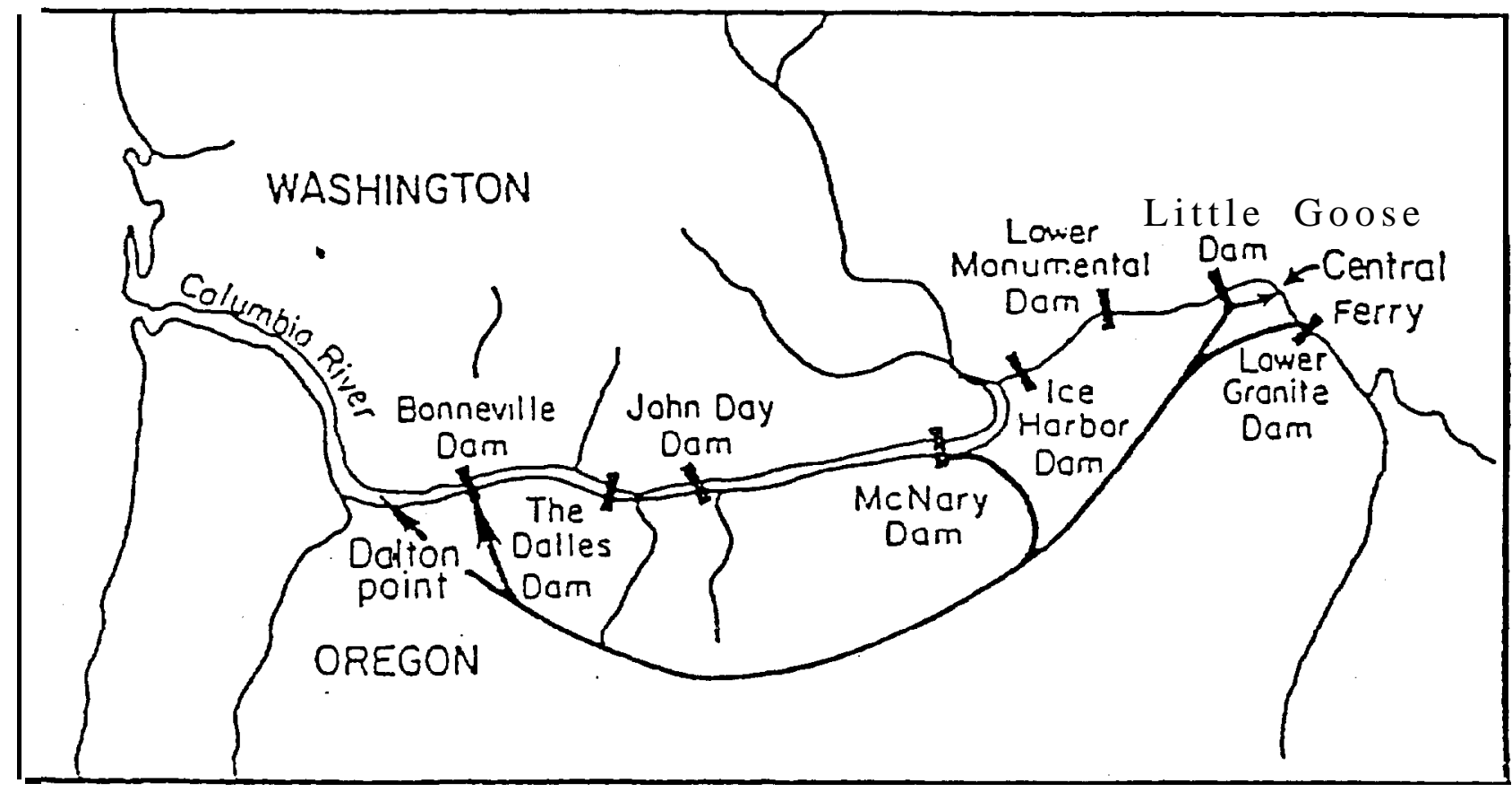

Figure 1. Transportation routes and release locations of experimental chinook and steelhead collected and marked at Ice Harbor, Little Goose, Lower Granite, and McNary Dams. 


\subsection{ACKNOWLEDGEMENTS}

The region's ratepayers funded this report through the Bonneville Power Administration. I thank Ms. Deborah Watkins, Project Manager, for her guidance and direction.

\section{FACTORS INFLUENCING TRANSPORTATIONSTUDY RESULTS}

Before an overview of salmon transportation, some insight may be gained by a review of factors that influenced the observed results of transport experiments. Obviously, in the past quarter century there have been many events on the river and changes in research techniques that could bear on the outcome of transportation experiments. In the interest of brevity, some factors will be grouped together. Those of greatest importance will be considered in some detail. The following factors are presented in order I believe are of greatest importance in assessing the results of transportation experiments.

\subsection{POPULATION STRUCTURE CHANGES}

In 1966, spring/summer chinook salmon smolts were first released from Rapid River Hatchery--then the only hatchery in the Snake River Basin. In 1968 Rapid River Hatchery released 1,460,000 spring chinook. salmon smolts (Chapman et al. 1991), and it had not yet reached full production. Since that time, production has been added from Kooski, Pahsimeroi, Sawtooth, McCall, and Dworshak Hatcheries in Idaho. Additional chinook releases come from Lookingglass Hatchery in Oregon. Numerous fry and fingerling outplants have been made to streams such as the Imnaha River in Northeastern Oregon and to various pond facilities (Chapman et al. 1991). All this has culminated in the release in 1992 of 11,025,000 spring/summer chinook salmon upstream from Lower Granite Dam (L. Basham, Fish Passage Center, personal communication).

Since 1970, the smolt population arriving at the upper dam (upper transportation site) has steadily shifted from one comprised mostly of wild fish to one comprised mostly of hatchery fish (Table 1). Raymond (1988) provides estimates of hatchery fish and wild fish arriving at the first dam in years 1964 to 1984. From the early years of hatchery production when wild fish still represented the majority of downstream migrants, numbers of wild fish have declined drastically. During 1992, the estimate for wild fish in the smolt population at Lower Granite Dam was 13\% (Borgerson, 1992). No estimate of population size was made.

Transportation experimental designs were based on the early high rate of return for the predominately wild population. As the population shifted to more and more hatchery fish, the transportation study results were compromised because of much lower survival rates of the hatchery component (Raymond 1988) Virtually all hatchery fish in the Snake River system carry Bacterial Kidney Disease (BKD: causative agent 
Renibacterium salmoninarum) resulting in very low survival compared with their wild counterparts (Matthews 1992). Consequently, in recent years study designs have had to be modified to allow for marking more fish to take into account the high mortality rate of hatchery fish.

Table 1. Estimated percent of smolt migration and ensuing adult runs composed of wild fish, grouped by transportation study years at Snake River dams (data from Raymond 1988, In Chapman et al 1991).

\begin{tabular}{lll}
\hline Years & $\begin{array}{l}\text { Percent of smolt } \\
\text { migration wild }\end{array}$ & $\begin{array}{l}\text { Percent of ensuing } \\
\text { adult run wild }\end{array}$ \\
\hline
\end{tabular}

Ice Harbor

$1968-70$

75

Little Goose

1971-73

52

61

Little Goose and

Lower Granite 1975-80

40

71

No transport studies

1981-84

18

50

1985-present

No wild to hatchery ratio estimated

\subsection{CHANGES IN THE HYDRO-SYSTEM}

During the early 1970s it was widely believed that the new dams and extended powerhouses planned would doom salmon and steelhead runs of the Snake River. New dams included John Day (1968), Lower Monumental (1969), Little Goose (1971), and Lower Granite (1975). The number of turbines on the Snake River increased 8-fold during the decade (Table 2). Additional turbine units were placed at John Day Dam, and at Bonneville Dam a second powerhouse was completed with 8 units in 1982. If turbine-caused mortality was the real culprit, new dams and turbines certainly justified the fear. There may, however, be another reason for the poor adult returns noted after 1975. 
Table 2. Number of turbines installed at Snake River dams, 1968 to 1979.

\begin{tabular}{llllll}
\hline Year & $\begin{array}{l}\text { Lower } \\
\text { Granite }\end{array}$ & $\begin{array}{l}\text { Little } \\
\text { Goose }\end{array}$ & $\begin{array}{l}\text { Lower } \\
\text { Monumental }\end{array}$ & $\begin{array}{l}\text { Ice } \\
\text { Harbor }\end{array}$ & Total \\
& & $\mathbf{0}$ & $\mathbf{0}$ & 3 & \\
1968 & 0 & $\mathbf{0}$ & $\mathbf{3}$ & 3 & 6 \\
1970 & 0 & $\mathbf{3}$ & 3 & 9 \\
1971 & 0 & $\mathbf{3}$ & $\mathbf{3}$ & 6 & 15 \\
1975 & 3 & $\mathbf{3}$ & $\mathbf{6}$ & 6 & 21 \\
1978 & 6 & $\mathbf{6}$ & & 6 & 24 \\
1979 & 6 & & & & \\
\hline
\end{tabular}

Near-equal adult return rates to the mid-Columbia and the Snake River seem to rule out transportation or new dams/turbines as a cause of low return rates for spring/summer chinook salmon and steelhead during 1976 to 1982 (Figure 2, from Park 1985). First, the rate of return of chinook and steelhead from both reaches was similar (actually slightly higher for Snake River segment). This is puzzling if added dams/turbine units in the Snake River were responsible for the decline. Second, up to this time (1982) mid-Columbia River fish were not subjected to transportation.

Steelhead returned at a very high rate (compared to chinook) to both regions in 1982. Steelhead continue to respond to transportation and other enhancement measures in the Snake River while returns to the mid-Columbia River remain below expectations. The health and smolt quality of spring/summer chinook is now a factor that more likely limits survival than passage through dams.

\subsection{IMPROVEMENTS TO JUVENILE FISH PASSAGE FACILITIES}

The new dams brought with them new bypass systems. Bypasssystems are key to any transportation system because without the system, meaningful numbers of fish can not be collected for transportation. Unfortunately the enclosed, pressurized pipe design that was incorporated into John Day (1968), Lower Monumental (1969), and Little Goose (1970) Dams did not work as planned. Fish had difficultly finding the orifices, others were descaled or injured, and many were trapped within the gatewells as orifices became completely plugged with debris. During the 1970s descaling became a new word in the fisheries literature and many descaled fish were marked for transportation evaluation. A summary of bypass/collection system development at transportation test sites follows (Park 1985): 


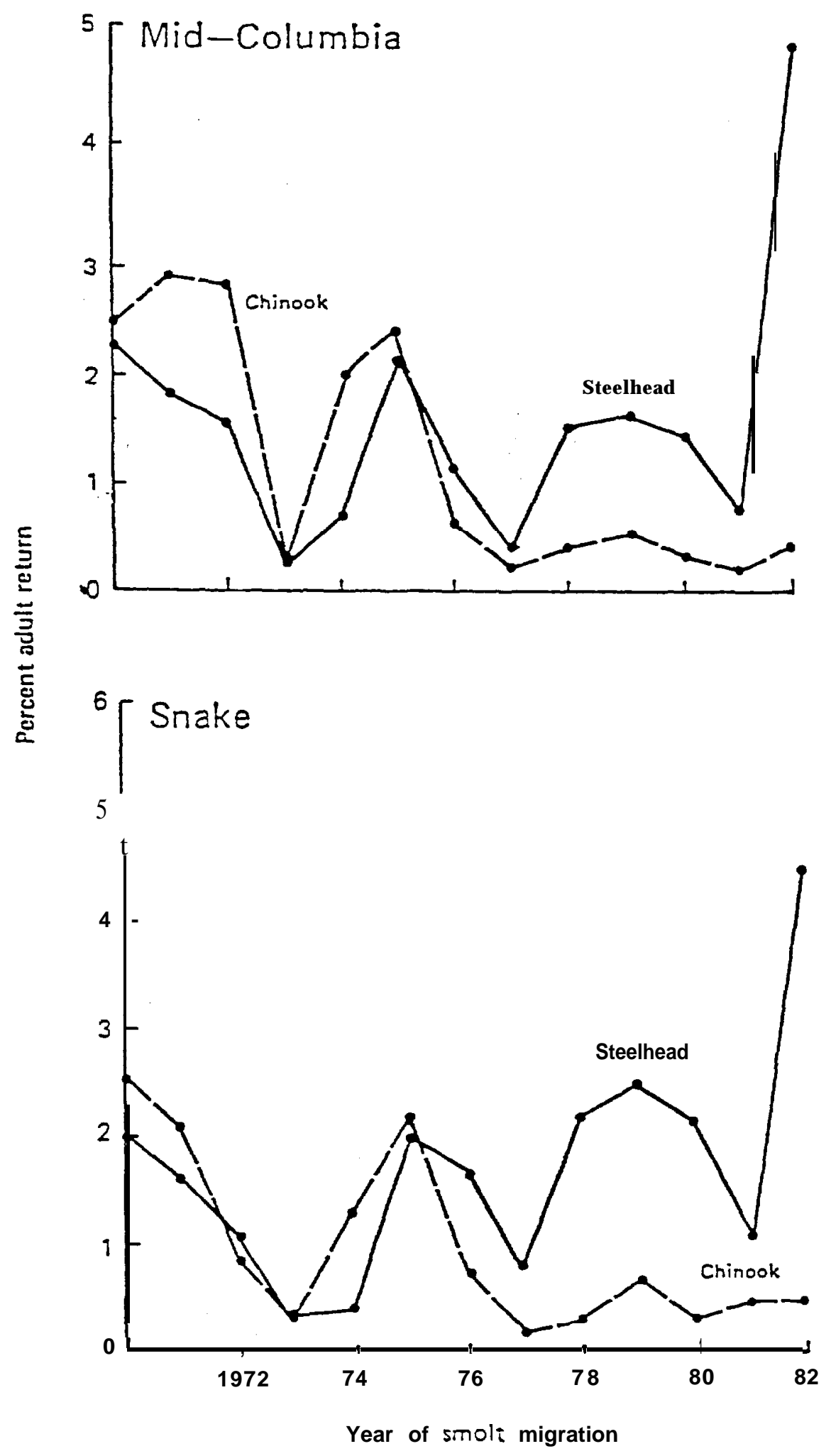

Figure 2. Percent return of spring chinook salmon and steelhead to the Snake and midColumbia rivers from smolt migrations 1970-1982. 
1. At Ice Harbor Dam (tests 1968-70) no traveling screens were used and a rudimentary bypass system was being developed. In 1969-70 high incidence of gas bubble disease caused by spilling entire flow at Lower Monumental dam (1969) and Little Goose Dam (1970) coupled with a less than satisfactory pump-lift system at Ice Harbor probably caused mortality that resulted in a much lower rate of return than observed in 1968 (Park et al. 1985).

2. At Little Goose Dam (tests 1971-78) traveling screens were developed, and by 1978 all generating units were screened. Throughout the period, the bypass system operated poorly (e.g., smolt descaling was high, debris was a problem, and delay in passage from gatewells was observed (Ebel 1980)). In 1985, the system was modified to include 12 -inch diameter orifices (formerly 6 in). The system still caused high descaling and was retrofitted again in 1990 (12 in orifices were retained) (Ceballos et al. 1991).

3. Lower Granite Dam (tests $1975-80$ and 1986 to present) was also fitted with a pressurized pipe but had 8-inch diameter orifices (Matthews el al. 1977). A major improvement was an open gallery located between the gatewell orifices and the pressurized pipe. As at Little Goose Dam descaling was initially unacceptable (6.4\%) (Park et al. 1976). Most of the descaling was attributed to poor functioning of traveling screens, but entrained debris (Matthews 1992) was also a major contributing factor.

\subsection{DEBRIS REMOVAL,FISH HANDLING, AND OTHER IMPROVEMENTS}

During 1981, the U. S. Army Corps of Engineers (USACE) began a major effort to collect and remove debris from the forebay at Lower Granite and other dams. The policy had a profound effect. It reduced descaling and injury in collection systems. Subsequently, as fish condition improved, survivability of transport test fish improved, and the rate of return of marked adults increased.

During the mid-1980s, a new fish procedure termed "pre-anesthesia" was developed (Matthews et al. 1986). The system allowed fish to be anesthetized before any handling or dipping. (Dipping fish from water, unanesthetized, is a common stress challenge test). As Matthews (1992) notes, "this system virtually eliminated the major physical traumas associated with the handling and marking process."

Debris removal was a benefit to all fish in the bypass/collection system, while the preanesthesia system was an additional benefit to the transport test fish. Recently, delayed mortality after marking has been one-eighth that observed during the late 1970s (Matthews et al. 1988). 
The USACE was given a major responsibility for operating the mass transport or "Operation Fish Run" in 1981. With their active role, they began an even more determined effort to correct transport equipment and facility deficiencies.

Chapman et al. (1991) chronicled more than 30 improvements at transportation dams from 1981 to 1990 . There were many others.

\subsection{NATURALEVENTS}

Some events have had severe negative effects on fish populations as a whole, and on transport test fish in particular. For example, during 1980 Mount St. Helens erupted, causing extremely poor water quality conditions in the Columbia River downstream from the Cowlitz River. That year over 95,000 spring/summer chinook salmon were marked at Lower Granite Dam for transport tests. Many of these fish were wild, based on estimates provided by Raymond (1988). A single adult returned from the barge group. No controls and no trucked fish returned, There is no explanation aside from the Mount St. Helens event.

The severa drought in the Snake River Basin during 1977 provides another case. Some argue that the more recent drought years were equally severe. I believe they were not. The river management entities were totally unprepared for conditions in 1977. Not only were facilities still in sad condition (noted earlier), but water managers had no experience in coping with the low-flow problem. In the 1977 year-class, two test fish returned from transport tests at Lower Granite Dam and none from tests at Little Goose Dam.

Natural events can also improve survival. Sometimes we are pleasantly surprised by "good" events. High ocean survival is one of these. The outmigration years of 198285 might fall in this category. Steelhead, fall chinook, and spring/summer chinook runs in the Columbia River Basin generally increased substantially during the period. The specific mechanisms that influence ocean survival are poorly understood (Solazzi et al. 1991). Upwelling has been identified as one factor contributing to survival (Nichelson 1986). Predation on all age groups of salmon in the ocean and near-shore areas (See Appendix on marine mammals) is a negative contributing factor.

\section{SUMMARY RESULTS OF SMOLT TRANSPORTATIONEXPERIMENTS 1968 TO 1992}

\subsection{SPRING/SUMMER CHINOOK SALMON}

The basic concept of smolt transportation involves collection of smolts at a dam (Figure 3, from Park 1985) and conveying them by truck or barge to a presumed safe location downstream from the lowermost dam (Bonneville Dam) on the Columbia River. Extensive procedural descriptions for transportation tests have been offered by Ebel et al. (1973), Park (1985), and Matthews (1992).

As mentioned earlier, transportation has been studied on the Snake River in most 

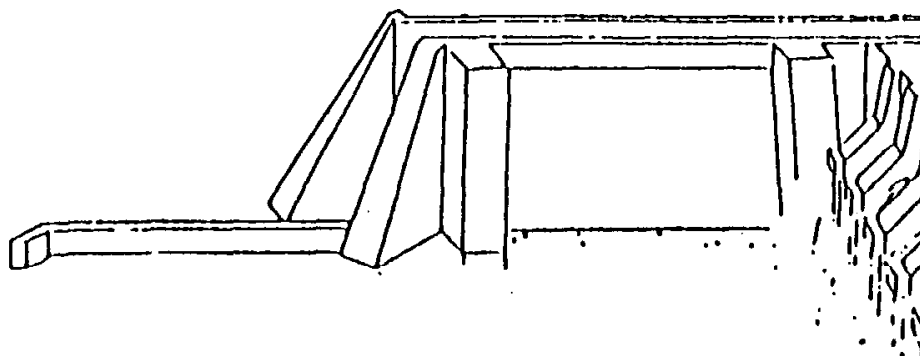

UNENILE SALMONID COUECTION

8. TRAMLSPORTAIION SYSTEM

(Lower Gronile Dam)

$\infty$

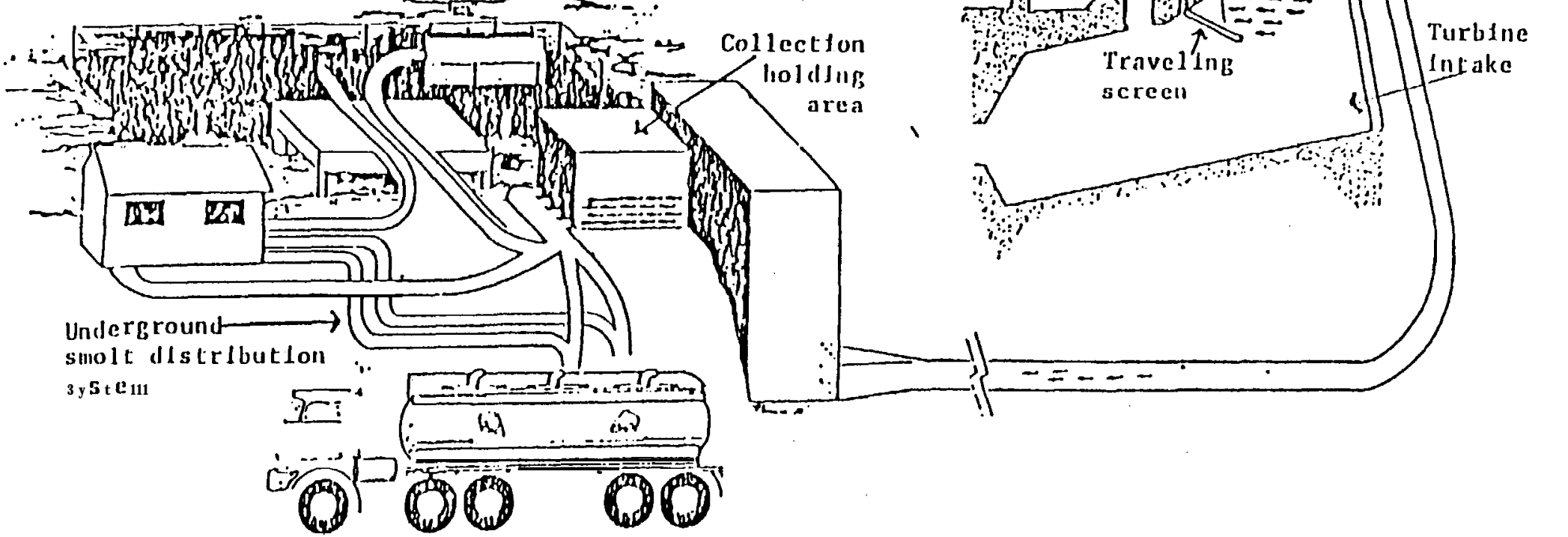

Figure 3. A cross section of a powerhouse at a major collector dam showing the typical collection and transport system including traveling screen placement, bypass channel and pipe to tailrace, holding ponds, and distribution system to trucks or barges. 
years since 1968. Studies shifted upstream as new dams were constructed and to different mainstem river sites as policy dictated. More recent studies have continued at Lower Granite because it is the uppermost dam where smolts can be collected and because many changes have occurred in collection, operations, fish handling, flow manipulation, and fish population structure. I believe that changes in spring/summer chinook salmon populations occasioned by increasing numbers of fish released from hatcheries have been the primary cause of blurring the measured results since 1976; and have caused transportation studies to continue without community agreement on whether that species should be transported.

A case history of the blurring effects of hatchery fish presents itself by a recent review of NMFS transportation studies by fisheries management agency personnel (Anonymous 1993). An attempt was made by the review staff to show that transportation does not benefit wild fish. The data of 1986 and 1989 (Lower Granite Dam tests) were reviewed for specific reference to wild fish survival following transport. For the study year 1986, 24 fish were recovered at tributary weirs and traps (presumed to be wild fish). Some of these fish were likely from releases of hatchery fish designed to supplement natural spawning stocks and none to my knowledge was recovered from the Middle Fork of the Salmon River where many of the wild fish in question spawn. In other words, most, if not all, of the 24 fish noted by the anonomous reviewers were actually of hatchery origin and could not be used for evaluation of transport benefits for wild fish.

Downstream migrants in 1986 were produced by spawners in 1984. The spring/summer chinook redd count in all indexed streams in 1984 was 884--second lowest on record (Matthews and Waples 1991). It is clear that there were few wild fish among many hatchery migrants in 1986 and the number of wild fish marked that year would be far too few to permit any reasonable analysis of transportation benefit for wild fish based on adult returns for that remnant group. It is inappropriate to speculate on effects of transport for wild fish when their numbers are known to have little or no influence in the designed study.

Efforts to reduce the effects of collection stresses and to increase survival of transported smolts led to experimentation with various transport media (Chapman et al. 1991). These included various concentrations of salt (sodium chloride and potassium chloride) and different mixtures and types of sedation during transport (Wedemeyer 1985). These experiments proved futile and only fresh river water is used in current truck and barge transportation.

Barge transport (McCabe et al. 1979) became the method of choice after the disastrous low flow in 1977. A barge/truck comparison study using spring/summer chinook was conducted in 1978 (Park et al. 1979). Results for the barged groups were favorable (barge TBR 8.92: 1 vs truck 5.77: 1, Table 3) and no further comparisons were tested.

Transportation results are usually stated as T/C (transport to control ratio) or TBR (transport benefit ratio). I use TBR in this report. The stated TBR is based on adults returning to the test site. 
Table 3. Percentage return and TBR of transported and non-transported spring/summer chinook salmon tested at Ice Harbor, Little Goose, Lower Granite, McNary, and Priest Rapids Dams during years 1968 to 1989. Data from Park (1985), Matthew et al. (1990), Matthews et al. (1992), Carlson et al. (1989), and Carlson and Matthews (1991).

\begin{tabular}{llll}
\hline $\begin{array}{l}\text { Dam, year, and } \\
\text { treatment group }\end{array}$ & $\begin{array}{l}\text { Number } \\
\text { juveniles } \\
\text { released }\end{array}$ & $\begin{array}{l}\text { Percent return } \\
\text { as adults } \\
\text { observed (estimated) }\end{array}$ & TBR \\
\hline
\end{tabular}

\section{ICE HARBOR 1968}

Control

John Day

Bonneville

\section{9}

Control

John Day

Bonneville

1970

Control

John Day

Bonneville

\section{LITTLE GOOSE} 1971

Control

Dalton Point

Bonneville 1972

Control

Dalton Point

Bonneville 1973

Control

Dalton Point

Bonneville 1976

Control

Bonneville/ freshwater

Bonneville/ 10 ppt saltwater
80,335

40,895

42,420

24,217

14,782

13,529

8,624

10,159

10,173 $\begin{array}{ll}0.14 & (4.3) \\ 0.16 & (4.7) \\ 0.30 & (9.0)\end{array}$

$0.19 \quad(0.5)$

$0.13(0.36)$

$0.24(0.58)$

$0.20(0.32)$

$0.07 \quad(0.11)$

$0.29(0.47)$
$1.14: 1^{* * *}$

2.14:1*

$0.66: 1^{* * *}$

1.26 : 1*

$0.35: 1^{* * *}$

1.45: 1*
20,673

30,637

35,252

32,836

51,499

54,906

88,170

57,758

83,606

42,046

68,605

82,082
$0.25 \quad(0.47)$

$0.39 \quad(0.76)$

$0.42 \quad(0.79)$

$0.08 \quad(0.10)$

$0.09 \quad(0.11)$

$0.08 \quad(0.11)$

$0.02 \quad(0.03)$

$0.42 \quad(0.73)$

$0.31 \quad(0.44)$

18.1:1*

13.5:1*

$0.02 \quad(0.09)$

$0.04 \quad(0.16)$

1.75:1***

$0.03(0.11)$
1.6:1* $1.7: 1^{*}$

1.1:1*** 1.1:1
$1.21: 1^{* * *}$ 
Table 3 continued.

Dam, year, and

treatment group

1977

Control

Bonneville/

freshwater

Bonneville/10 ppt

saltwater

1978

Control

Bonneville/FW

Bonneville/ 10 ppt saltwater

LOWER GRANITE 1975

Control

Bonneville/truck

1976

Control

Bonneville/truck

freshwater

Bonneville/truck saltwater 1977

Control

Bonneville/truck saltwater

Bonneville/barge

1978

Control

Bonneville/truck freshwater

Bonneville/barge

1979

Control

Bonneville/barge

1980

Control

Bonneville/barge

1986

Control
Number

juveniles

released

38,346

41,677

43,334

36,441

49,391

47,661

43,902

68,550

28,686

72,918

61,446

38,346

45,404

31,628

36,441

43,855

56,546

25,532

27,336

21,876

40,719

45,035
Percent return

TBR

as adults

observed (estimated)

$0(0)$

$0(0)$

a/

$0(0)$

a/

$0.01(\underline{a} /)$

$0.01(\underline{a} /)$

a/

$<0.01(\underline{\mathrm{a} /})$

a/

$0.31(0.86)$

0.64 (1.75)

2.03: 1*

$0.04(0.11)$

$0.03(0.07)$

$0.66: 1^{* *}$

$0.04(0.11)$

$1.00: 1^{\text {****}}$

$0(0)$

$\operatorname{co.01}(\underline{a} /)$

$\operatorname{co.01}(\underline{\mathrm{a}} /)$

a/

al

$0.01(0.04)$

$0.08(0.23)$

5.77: 1*

$0.12(0.35)$

8.92: 1*

$0.01(0.08)$

$0.04(0.30)$

3.92: 1*

0 (0)

$<0.01(\mathrm{a} /)$

a/ 
Table 3 continued.

\begin{tabular}{|c|c|c|c|}
\hline $\begin{array}{l}\text { Dam, year, and } \\
\text { treatment group }\end{array}$ & $\begin{array}{l}\text { Number } \\
\text { juveniles } \\
\text { released }\end{array}$ & $\begin{array}{l}\text { Percent return } \\
\text { as adults } \\
\text { observed (estimated) }\end{array}$ & TBR \\
\hline $\begin{array}{c}\text { Bonneville/barge } \\
1989\end{array}$ & 45,004 & $0.16(0.48)$ & $1.60: 1^{*}$ \\
\hline $\begin{array}{l}\text { Control } \\
\text { Bonneville/barge }\end{array}$ & $\begin{array}{l}107,176 \\
75,295\end{array}$ & $\begin{array}{l}0.024(\underline{\mathrm{a}} /) \\
0.060(\underline{\mathrm{a}} /)\end{array}$ & $2.50: 1^{*}$ \\
\hline \multicolumn{4}{|c|}{$\begin{array}{l}\text { PRIEST RAPIDS DAM } \underline{b} / \\
1984\end{array}$} \\
\hline Control & 38,247 & $0.165(\underline{a} /)$ & \\
\hline $\begin{array}{c}\text { Bonneville/truck } \\
\mathbf{1 9 8 5}\end{array}$ & 38,673 & 0.096 (a) & $0.58:$ a \\
\hline Control & 49,700 & $0.181(\mathrm{a} /)$ & \\
\hline $\begin{array}{c}\text { Bonneville/truck } \\
1986\end{array}$ & 50,490 & $0.315(\mathrm{a} /)$ & 1.74: 站 \\
\hline Control & 35,595 & $0.057(\mathrm{a} /)$ & \\
\hline Bonneville/truck & 34,648 & $0.05 \quad(\underline{a} /)$ & $0.88:$ la \\
\hline
\end{tabular}

a /: $\quad$ No returns were observed, there were insufficient returns for analysis, or no analysis was made.

b/: $\quad$ Returns are combined for trap sites at Priest Rapids, McNary, and Bonneville Dams.

*: $\quad$ Significantly more transported fish returned than controls, $\mathrm{P}<0.05, \mathrm{df}=1$.

**: $\quad$ Significantly less transported fish returned than controls, $\mathrm{P}<0.05, \mathrm{df}=1$.

***: No significant difference between return of transported and control fish.

Spring/summer chinook salmon were marked for transportation tests during 197880 at McNary Dam. Returns for these tests were so few that analysis of the data was not possible (Park 1985). The study was repeated during 1986-89. Returns again were very poor. However, Matthews et al. (1992) gives a preliminary TBR of 1.7: 1 (range 0.6: 1 to 5.1: 1,CI 95\%) for 1987. Date were incomplete in 1989. More fish were marked for the later series than the earlier one. Still, meaningful results were not obtained. I suspect that an important reason was that the population was predominantly hatchery fish. The fish quality decreases as the population moves seaward, apparently because the severity of BKD increases as time passes following release from the hatcheries (Pascho and Elliott 1989). Another explanation is that smolts are simply worn out from passage through dams and bypass systems. The spring chinook data for Priest Rapids Dam are still in preliminary status. 


\subsection{SOCKEYE SALMON - PRIEST RAPIDS DAM}

Mid-Columbia River sockeye salmon transportation studies were unique in that the fish were entirely from wild origins. No hatchery stocks have supplemented the run since 1966. Studies began in 1984 and marking concluded in 1988. Adult return data and TBRs are presented in Table 4. As noted above for chinook, no detailed analysis is published at this time.

Table 4. Percentage return and TBR of transported and non-transported sockeye salmon tested at Priest Rapids Dam during years 1984 to 1988. Data from Carlson et al. (1988), Carlson et al. (1989), Carlson and Matthews (1991), and Carlson and Matthews (1992).

\begin{tabular}{|c|c|c|c|}
\hline $\begin{array}{l}\text { Dam, year, and } \\
\text { treatment group }\end{array}$ & $\begin{array}{l}\text { Number } \\
\text { juveniles } \\
\text { released }\end{array}$ & $\begin{array}{l}\text { Observed percent } \\
\text { return as } \\
\text { adults a/ }\end{array}$ & TBR \\
\hline 1984 & & & \\
\hline Control & 20,674 & 0.416 & \\
\hline $\begin{array}{c}\text { Bonneville/truck } \\
\mathbf{1 9 8 5}\end{array}$ & 20,731 & 0.381 & $0.92: 1$ \\
\hline Control & 55,432 & 0.85 & \\
\hline $\begin{array}{c}\text { Bonneville/truck } \\
\mathbf{1 9 8 6}\end{array}$ & 55,406 & 1.71 & 2.02: 1 \\
\hline Control & 50,642 & 0.355 & \\
\hline $\begin{array}{c}\text { Bonneville/truck } \\
1987\end{array}$ & 49,963 & 0.226 & $0.64: 1$ \\
\hline Control & 18,078 & 0.841 & \\
\hline Bonneville/truck & 17,931 & 1.283 & $1.53: 1$ \\
\hline $\begin{array}{c}\text { Bonneville/truck/barge } \underline{\mathrm{b}} \\
\mathbf{1 9 8 8}\end{array}$ & 10,770 & 1.031 & 1.23: 1 \\
\hline Control & 18,078 & 1.11 & \\
\hline Bonneville/truck & 17,931 & 1.7 & $1.53: 1$ \\
\hline Bonneville/truck/barge & 10,770 & 1.43 & $1.29: 1$ \\
\hline
\end{tabular}

a/: $\quad$ Returns to Bonneville, McNary, and Priest Rapids Dams are combined.

b/: The barge group consisted of smolts that were trucked to McNary Dam and offloaded to a USACE fish transportation barge. 


\subsection{FALL CHINOOK SALMON}

Transportation tests were conducted at McNary Dam from 1978 to 1983. The species was retested from 1986 to 1989. Generally, marked (tagged) fish returning to McNary were few; however, returns in the ocean catch were abundant, so those data were analyzed to establish TBRs (Table 5).

Table 5. Percentage return to ocean and Columbia River net fisheries and TBR of transported and non-transported fall chinook salmon tested at McNary Dam 1978 through 1989. From Park et al. 1982, Matthews et al. 1988, and Matthew et al. 1992.

Year and

treatment group

1978

Control

Bonneville/truck 1979

Control

Bonneville/truck

1980

Control

Bonneville/truck

1981

Control

Bonneville/truck

1982

Control

Bonneville/truck

1983

Control

Bonneville/truck

Bonneville/barge

1986a /

Control

Bonneville/barge

1987 al

Control

Bonneville/barge
Number juvepiles

released

132,919

84,587

80,204

42,580

42,924

38,683

39,693

40,301

35,279

38,860

115,991

114,653

68,291

68,376
Percent return

observed

0.032

0.176

0.044

0.325

TBR

0.118

0.432

3.7: 1*

0.215

0.678

$3.15: 1^{*}$

0.183

0.409

2.64: $1^{*}$

0.201

0.480

0.436

2.39: $1^{*}$

2.17:1*

0.14

0.40

2.8: 1

0.14

0.52

3.7: 1 
Table 5, Continued.

\begin{tabular}{lll}
\multicolumn{1}{c}{ 1988a/ } & \\
Control & 60,010 & 0.02 \\
Barge & 60,013 & 0.06
\end{tabular}

$\underline{\mathbf{a} /:} \quad$ Observed returns are from commercial and sport ocean and Columbia River fisheries.

b/: $\quad$ Statistical analysis is not complete for any year and total returns are not complete for 1987 and 1988.

\section{INTERPRETATION OF TRANSPORT RESULTS}

\subsection{SPRING/SUMMER CHINOOK SALMON}

At the Snake River Dams a total of 29 tests have been reported. Of these, 13 had statistically significantly more transported fish return than control fish. In eight tests there were no significant difference among test groups, too few returns occurred for analysis in 7 tests, and in one test significantly more controls returned than did transported fish. I disagree with Matthews (1992) who argues that in the latter c\&e (Lower Granite 1976), the two test groups (experiments) should be combined, resulting in one test with insignificant findings.

Early experiments provide the most compelling evidence for the benefits of transportation. For example, Ebel et al. (1973) report an estimated 9\% return for transported groups, or 3818 adults back to Ice Harbor Dam in 1968. Park et al. (1979) estimated that 1194 (1.7\%) adults returned from smolts transported to Bonneville Dam in 1975. Matthews et al. (1992) shows that 74 and 45 adults returned to Lower Granite Dam from transport releases in 1986 and 1989 respectively. These numbers can be expanded to a liberal estimate of about $222(0.48 \%)$ and $135(0.18 \%)$ respectively. In all years the results were statistically significant. The point is: results of the earlier studies when a large percentage of the run consisted of wild fish are much more powerful and consequently should be given more weight in making management decisions on transportation of wild fish.

To place a different perspective upon the Ebel et al. (1973) and Park et al. (1979) estimates of transport return, I refer to Raymond (1979). He estimated that in 1968, 2.6 million smolts (20\% were of hatchery origin) produced a total run of 104,000 (including fisheries) or 4.0\% return. The data of Ebel et al. (1973) indicate an estimated 9.0\% return with a TBR of slightly more than $2: 1$, so their estimate is certainly consistent with Raymond.

The Park et al. (1979) estimate is somewhat more difficult to interpret in this light. Raymond estimated that the 1975 smolt outmigration consisted of about 55\% 
hatchery fish (4.0 million total). Park et al. (1976) reported that marking for transport tests at Lower Granite Dam began on April 23--a date that normally coincides with the peak of hatchery-fish emigration. Therefore, marked fish for the study were not randomly marked throughout the run, as at least half of the hatchery fish had passed the dam before marking began (about 20\% of the test fish were marked prior to May 5), resulting in an undetermined bias toward wild fish in the marked groups. I believe that at least $60 \%$ of fish marked were wild fish. Raymond reports that $2.6 \%$ of the 1975 outmigration returned to the Columbia River. The estimate of Park et al. (1979) of $1.75 \%$ return of transported fish (2: 1 TBR) was likely consistent with Raymond; given that no estimate of fisheries harvest was made, and that by 1975 any hatchery fish marked had reduced survival capability. The rate of return of wild fish was about 3.5 times that of hatchery fish (Raymond, 1979).

Raymond (1988) provides a comparative rate of adult return for hatchery and wild fish during the years 1966 to 1984. It is revealing that from 1966 to 1971 the rate of return of hatchery fish was essentially the same as the rate for wild fish. Beginning in 1972, however, the rate declined and by' 1978 the rate of return of hatchery fish was one tenth that of wild fish.

Giorgi (1991) estimated that survival of smolts to the first dam was only $8.0 \%$ to $52.8 \%$ among three hatcheries studied. He further noted that survival to the first dam is one-fifth to one-half that observed during the 1960s. Matthews (1992) addresses the poor survivability of transported hatchery smolts: "Smolt transportation, however, will not and should not be expected to mitigate for progressive overproduction of hatchery populations with grossly inferior survival capabilities".

Wild fish receive more benefit from transportation than do hatchery smolts. Wild steelhead transported in 1986 returned at a rate of $1.50 \%$, while the rate for the hatchery group was $0.81 \%$ (Matthews et al. 1990). It has not been possible to measure the absolute differential rate of return for wild and hatchery spring/summer chinook salmon stocks. Nevertheless, a review of the chinook transport data strongly suggests that when wild fish have been the predominant stock in transport tests they benefit far more from transportation than do hatchery fish.

Another indicator that transportation has aided wild fish was the tremendous rebound in redd counts (wild adults) in the Grande Ronde, South Fork of the Salmon, and the Middle Fork of the Salmon Rivers during the mid-1980s (Matthews and Waples 1991). In 1988, all three rivers had the highest counts since 1973, with the South Fork approaching pre- 1965 counts. Matthews (1992) observed that the redd recruitment ratio for the 1980-1984 spawning generation had increased to 3.4 recruits per redd. More than $50 \%$ of the smolts were transported in years that led to rebuilding the adult stocks.

I conclude that transportation can and should be used throughout the full range of flow and dam operating conditions by managers when considering recovery measures for listed spring/ summer chinook salmon.

\subsection{SOCKEYE SALMON}

Sockeye salmon migrate seaward with the spring/summer chinook salmon in the 
Snake River. Furthermore, they are of similar size, so if one species is transported, the other will be also. I mention the size relationship because at some dams so-called "wet separators" are used to separate large fish (steelhead) from small fish (sockeye, spring/summer chinook, etc). I understand that a "wet separator" is planned for installation at Lower Granite Dam. It should be implemented as soon as possible so that steelhead can be transported separately from chinook and sockeye salmon.

There are no conclusive published data on the merits of transporting sockeye salmon and there are no data exclusive to Snake River sockeye. The TBRs listed in Table 4 are somewhat encouraging. I suspect that 1985 may be the only year with positive significant results because returns were numerous. The results in 1987-88 may prove significant, but the sample size is small. I doubt that the 1984 and 1986 results will be negatively significant because of few adult returns.

The mid-Columbia River sockeye data probably should be ignored. Matthews (1992) states: "I suspect that most of these studies were encumbered by mechanical flaws during the release of the trucked groups, a poor truck release site or both". I agree with this assessment except that if the flaws existed, they would apply to all, not most of the studies. Sockeye transportation on the mid-Columbia River should be re-evaluated, especially if a bypass system is installed there or if more detailed information is required on responses of sockeye salmon to transport.

Snake River sockeye salmon should be transported with spring/summer chinook salmon in lieu of contrary transport research information.

\subsection{FALL CHINOOK SALMON}

Fall chinook salmon should be transported. No specific studies have been conducted using Snake River fish. However, the evidence for transporting fall chinook salmon from McNary Dam is extensive (Park 1985, Matthews et al. 1987, Matthews et al. 1988, and Matthews et al. 1992).

\section{EFFECT OF TRANSI'ORTATIONON HOMING}

Loss of homing can be characterized as straying, "wandering" (described by Chapman et al. 1991), or a delay in migration (Park 1985). In review of transport data, I found no instance of delay reported for the salmon species. There may have been cases of wandering. Park (1985) summarized straying in tests through 1980. Eleven strays were noted for spring/summer chinook--all in the Deschutes River, Oregon. It is possible some of these were wanderers in that they were intercepted at the hatchery and became trapped. No homing interruptions have been identified for fall chinook salmon.

For tests at Priest Rapids Dam, straying is reported in Table 6 (from Carlson et al. 1988, Carlson et al. 1989, Carlson and Matthews 1991, Carlson and Matthews 1991, and Carlson and Matthews 1992).

When one considers that thousands of transported spring/ summer chinook and sockeye salmon have returned to the Columbia River, the few strays observed appear 
Table 6. Straying by spring/summer chinook and sockeye salmon by year of release and area of recovery.

$\begin{array}{lccl}\text { Species } & \text { Number of fish } & \text { Year of release } & \text { Recovery area } \\ \text { Spring/summer } & 2 & 1984 & \text { Deschutes R., OR } \\ \text { Spring/summer } & 1 & 1985 & \text { Deschutes R., OR } \\ \text { Sockeye } & 1 & 1985 & \text { Cascade Hatchery } \\ \text { Sockeye } & 1 & 1987 & \text { Lower Granite D } \\ \text { Sockeye } & 2 & 1987 & \text { Deschutes R., OR } \\ \text { Sockeye } & 1 & 1987 & \text { Bonneville Hat. }\end{array}$

Total 8

inconsequential. Ebel (1980), Park (1985), and Matthews (1992) concur that straying of transported fish has had little affect on TBRs and probably little, if any, effect on natural spawning populations.

When straying does occur, there seems to be a propensity for fish to seek the Deschutes River (Snake River steelhead have been observed there also). Transportation should be used as an adaptive management tool while straying is better defined through research (see discussion on future research).

\section{POINT-OF-ORIGIN TRANSPORTATIONSTUDIES}

There have been numerous studies undertaken to increase survival of smolts by transporting them directly from hatcheries to various points downstream, some as far as $38 \mathrm{~km}$ offshore from the mouth of the Columbia River (Solazzi et al. 1991). In some cases homing was desired (Harmon and Slatick 1986), in others homing was of little or no consequence (Vreeland and Wahle 1983). The tests all used steelhead or coho salmon.

During 1971-1972, spring chinook salmon were transported from Rapid River to Bonneville Dam (Doug Webber, NMFS, personal communication). Returning adults were recovered from Columbia River net fisheries and at trapping facilities at Little Goose Dam. None returned to Rapid River. Ebel (1970) found that fall chinook salmon survival could be increased as fish were transported and released progressively downstream from above Bonneville Dam to Beaver Terminal in the Columbia River estuary. The greatest increase occurred between releases just above and below the dam. Evaluation was based on juvenile recovery in the estuary. Solazzi et al. (1991) found 
that survival (contribution to fisheries) increased sharply and significantly when they transported coho salmon from Bonneville Hatchery to Tongue Point in the estuary. Releases farther out into oceanic areas fared little better than the control released at the hatchery. It appears that transport stresses in the deck tanks, predation, or release into unproductive waters negated any benefits gained from bypassing the riverine mortality factors.

The present transport of Snake River fall chinook salmon from Lower Granite Dam differs from point-of-origin transportation. These fish have had migration experiences through the Lower Granite pool and are, therefore, more typical of the fish intercepted for transportation at any dam.

Based on present methodologies, it is unlikely point-of-origin transport of wild fish can benefit recovery efforts for listed species. Hatchery-reared steelhead and spring/summer chinook could be used. For example, hatchery fish could be transported direct to lower Columbia River sites to establish terminal fisheries, if those fisheries were absolutely limited to harvest of targeted hatchery fish. Alternatively, hatchery fish might be transported from natal hatchery to barges reserved for hatchery fish. Means must be researched and developed to assure adequate homing of such transported fish as adults.

\section{DISEASE IN TRANSPORTED FISH AND TRANSPORT SYSTEMS}

Disease in transported fish was virtually unknown during the early years of Snake River transportation studies. During the smolt migration in 1972 the first fish with gross 'symptoms of BKD were observed at Little Goose Dam (Chapman et al. 1991). The NMFS researchers became increasingly concerned about the presence of disease in the juvenile fish; During 1976 they examined 30 moribund fish with gram-staining techniques for presence of BKD (Park et al. 1977). They found 9 positive fish and BKD was considered the probable cause of death. Chapman et al. (1991) considered other diseases and factors contributing to disease, but BKD is of such overwhelming importance that this discussion will be limited to that disease.

Recognizing the potential for BKD interactions in the transport systems, the U.S. Fish and Wildlife Service (USFWS) began a study to evaluate the effects of the disease on transported and non-transported fish. During 1990, about 93\% (depending on the dam where data were examined) of the spring/summer chinook salmon were infected with R. salmoninarum as determined by enzyme-linked immunosorbent assay (ELISA) techniques (Elliott and Pascho 1992). Not all fish infected with the disease will die. However, the USFWS researchers have determined that the disease becomes more severe as the fish move downstream. Banner et al. (1982) found that mortality attributed to BKD ranged from 45 to $81 \%$ among three Oregon stocks of chinook salmon when held $200 \mathrm{~d}$ in salt water. This gives rise to the fear that in infected fish the severity of the disease and the death rate will increase as smolts enter the ocean.

On May 11, 1990 the bacterium was successfully cultured from water taken from the fish transport barge at McNary Dam (Elliott and Pascho 1992). This finding is alarming, but worse is the presumptive presence of the bacterium identified by 
fluorescent antibody techniques (PAT) in water samples taken at Lower Granite, Priest Rapids, McNary, and Bonneville Dams (upstream face); and from fish collection raceways at dams where such facilities occur (Elliott and Pascho 1992). In other words, given enough trials, it appears the disease could be cultured from river water throughout the Columbia and Snake Rivers wherever infected fish migrate. This is a critically important situation.

Logic dictates that the bacterium is pervasively present because it is shed into the water as fish migrate. Other sources might include resident salmonids and hatcheries. It is so pervasive that virtually all spring/summer chinook salmon now carry the disease. In wild fish, prevalence of the disease was high but the severity was low compared with levels in hatchery fish (Elliott and Pascho 1992). The only logical and readily available method for reducing the number of bacteria in the water mass is to reduce the number of fish that are currently released from hatcheries. Alternatively, a stringent culing and treatment program such as used at hatcheries on the Grande Ronde River may prove useful.

In 1992, 11,025,000 hatchery-reared spring/summer chinook were released from hatcheries. An examination of the historical record shows that the escalating number of fish released has produced a corresponding decline in adult return rates. The only spring/summer chinook salmon hatchery to show a positive correlation between smolts produced and adults returned to the hatchery is Rapid River (Chapman et al. 1991). Raymond (1979) estimated that in 1968, 2.6 million smolts arriving at Ice Harbor Dam and produced an ensuing run of 104,000 adults. It seems likely that smaller releases of more viable juveniles might produce more adults and at the same time reduce exposure of all fish, especially listed wild fish, to BKD. At present rates of return of hatchery fish it is nearly impossible to design experiments that rely on adult evaluation because the return rate is so dismal.

During 1990, live box tests were conducted in the transportation barge (Elliott and Pascho 1992). Brook trout (Salvelinus fontinalis), a species considered to be very susceptible to R. salmoninarum, were held during transport. During holding in freshwater following transport, the disease was not detected, indicating that the disease was not transmitted horizontally. However, in 1989, transmission did occur in similar tests. The authors suggested that in 1990, migrating fish had lower infection levels than in 1989, explaining the difference in horizontal transmission. The disease does not transmit easily in a horizontal mode because the organism is short-lived outside the host. Therefore, I believe absence of transmission in 1990 also suggests that fewer infected fish (fewer hatchery fish) would tend to reduce horizontal transmission during collection and transport procedures. The result would be fewer disease organisms per liter, and fish loading density would be reduced.

Matthews (1992) observed that all salmonid species, including steelhead and coho salmon, are infected at about the same rate as spring/summer chinook salmon. It appears there is little risk from increasing BKD infection levels among the listed species (the disease is already present in wild fish tissue) in relatively close confines of the transportation barge. Transportation should continue concomitantly with efforts to reduce hatchery fish and the persistent BKD organism. 


\section{TRANSPORTATIONBENEFITS FOR WILD FISH}

As has been already noted, significant numbers of wild fish were present in the Snake River downstream migrations of 1968 and 1975. Raymond (1988) estimated that 1974 was the last seaward migration in which wild fish numbers equaled or exceeded the hatchery component. To best analyze the benefit for transporting wild smolts, data from the period when wild smolts were abundant in the migration and when the adult return data were powerful should be used so that we are confident of accurate results. It is necessary also to keep in mind that mass transportation of smolts was not implemented at Lower Granite Dam until 1977. By that time the wild chinook salmon population had already declined to about 600,000 smolts.

The year 1975 best fits the conditions for an analysis of transport benefits for wild fish. Though the 1975 smolt migration had more hatchery fish than wild fish, I estimate that the majority of the fish marked were wild fish. This is supported by the fact that 37 tags from the test, were recovered from approximately 2,500 carcasses inspected on the spawning grounds. At hatcheries, where about 10,000 adults were inspected for tags, 36 tags were recovered. The only other possibility is that more hatchery fish than wild fish were marked. However, the survival rate of hatchery fish was then even lower than Raymond's estimate. Another reason for using the 1975 data is that flow conditions were good and survival of in-river migrants should have been optimum. The TBR measured for 1975 was a modest 2.14: 1, indicating that survival conditions were good. (Note: In 1973, survival of in-river smolts was very poor (Raymond 1979) and the TBR was 13.5: 1 for the Bonneville release.)

I use Raymond (1988) for estimates of wild spring chinook smolts and ensuing returns of wild spring chinook adults. I use Park et al. (1978) for estimates of rate of return for transported and non-transported fish (TBR). Rates of return for transported (and inriver migrants) should be higher than those for transport and control test fish because "production" transported fish are not handled for marking. My estimate is for expected return of wild spring chinook salmon emigrating from the Snake River in 1975 if mass transportation had been implemented. The number of fish that could have been transported reflects collection or fish guidance efficiency (FGE). FGE has varied substantially from year to year and from test to test within years. A range of FGE that corresponds to percent of fish that could have been transported is presented. Transport benefit is 2.14:1 (average of two treatment groups in 1975).

Example: If $60 \%$ of the smolts were collected and transported, then $60 \%$ would receive a transport benefit of $2.14: 1(63,000 \times 1.6 \times 2.14=80,900)$. The remaining $40 \%(25,200)$ would have returned without transport assistance (i.e., under the prevailing conditions). 


$\begin{array}{clll}\begin{array}{l}\text { Per cent FGE/ } \\ \text { transported }\end{array} & \begin{array}{l}\text { Number adults } \\ \text { returning with } \\ \text { benefit }\end{array} & \begin{array}{l}\text { Number adults } \\ \text { returning with- } \\ \text { out benefit }\end{array} & \begin{array}{l}\text { Total adults } \\ \text { estimated }\end{array} \\ 70 & 94,374 & 18,900 & 113,274 \\ 60 & 80,900 & 25,200 & 106,100 \\ 50 & 67,410 & 31,500 & 98,910 \\ 40 & 53,928 & 37,800 & 91,728 \\ 30 & 40,446 & 44,100 & 84,546 \\ 20 & 26,964 & 50,400 & 77,364 \\ 10 & 13,482 & 56,700 & 70,182\end{array}$

Though a range of values are presented above, I believe at least 50\% FGE can be achieved. The data of Giorgi et al. (1988) indicate that spring/summer chinook that are fully smolted are more susceptible to guidance than are presmolts. It is generally believed that wild fish are fully smolted when they arrive at Lower Granite Dam. Therefore, FGE for wild fish may be higher than for the population as a whole.

If collection and mass transportation facilities had been fully installed at Lower Granite Dam in 1975, I estimate that the net benefit would have been about 30,000 adults. I am confident the number illustrated above could be achieved for wild fish. For optimal benefit, the fish delivered to collection raceways must be in good condition. If they are in poor condition (i.e., descaled or injured) the relative benefit will be the same, but total return will be reduced.

\section{MODELING SMOLT TRANSFORTATIONBENEF'ITS}

There have been numerous attempts to model transportation benefits for spring/summer chinook salmon. Among these are System Planning Model (SPM), SLCM, CRISP, FISHPASS, and PAM (McConnaha 1991, Anderson and McConnaha 1992). This section, though it is not intended as a comprehensive review, will point out some major deficiencies of recent modeling efforts. Assumptions underlying modeling efforts are likely either invalid, or cannot be tested, or both. For example, McConnaha (1991) postulates that once the fish are in the barge or truck, their survival to adult return is not dependent on factors that affect the survival of non-transported fish. The assumption does not take into account the disease history of the fish. Survival to adult will be affected by disease in both transported and non-transported fish, and possibly at differential rates. A related assumption offered by McConnaha (1991) states that survival of transported fish is constant regardless of where the fish (smolts) were collected. Equal survival of transported fish collected at Lower Granite Dam and those collected at McNary Dam is not, and should not, be expected. Fish collected at these sites are from different sources (i.e., at Lower Granite fish are entirely of Snake River origin while at McNary they are mostly from the mid-Columbia River) and as such they may have different levels of disease, different wild fish stocks, and a host of other 
factors. Transportation tests to date show that when studies occurred at both Lower Granite and McNary Dams in the same years, returns were substantially less from McNary transported groups than for corresponding Lower Granite groups. In 1986, $0.02 \%$ and $0.16 \%$ return were observed for McNary and Lower Granite respectively (Matthews el al. 1992).

Even if fish populations that arrive at collector/transport dams were identical, post-transport survival may be vastly different. Descaling, injury, and mortality rates during collection have varied considerably from dam to dam within the same year (Koski et al. 1990). Therefore, it must be assumed that fish at different transport sites will have unequal, rather than equal, chances of survival when transported.

I agree with modelers that the expected TBR will be highest at the uppermost dam. This is logical because the more dams, reservoirs, and bypass systems smolts must pass through (controls), the higher mortality will be, and hence, the greater will be TBR.

Other model parameters associated with transportation may be plagued with erroneous values. Matthews (1992) implies that $15 \%$ mortality per dam may no longer be a useful value. He believes that the 1970s data reflect a much higher mortality at the first project encountered (i.e., Lower Granite Dam on the Snake River). Presumably, lower dams should be assessed a reduced mortality rate.

In the PAM Model (and others), the $98 \%$ survival value used for bypass efficiency is spurious. Results from 1992 comparative survival tests at the Bonneville Dam First Powerhouse indicate that fish released through the bypass and tailrace had the lowest survival of all treatment groups--28.3\% lower than the downstream release (control) (Dawley et al. 1992). Survival was significantly higher for fish passing through the First Powerhouse turbines and tailrace compared with the bypass group. Managers are presently considering pulling traveling screens at the First Powerhouse because mortality is so high in the bypass system (L. Basham, Fish Passage Center, personal communication). Findings were similar, though not as dramatic, in studies at the Bonneville Second Powerhouse (Ledgerwood et al. 1990). Bonneville Dam represents the first dam where survival through bypass systems has been comprehensively studied and the results are not encouraging. We know now that bypass mortality exceeds $\mathbf{2 \%}$-and by a huge margin. Unfortunately, high bypass survival values are being used as a part of the modeled survival values attributed to inriver migrants (controls in transport tests) and then compared to the survival of transported fish. These analyses are not useful unless accurate, up to date values are applied.

I conclude that modelers need more transport benefit data--especially at dams other than Lower Granite. Other parameters such as bypass survival values used in conjunction with transportation analyses need to be brought up to date before transportation effects can be modeled effectively.

\section{TRANSPORTATION: AN ALTERNATIVE TO SCREEN AND BYPASS}

Use of traveling screens and the accompanying bypass systems has spread throughout the Snake and Columbia Rivers. Screen/ bypasses are either installed or 
planned at all dams from Lower Granite to Bonneville. In light of bypass evaluations recently conducted at Bonneville Powerhouses I and II (see previous section), one must question the utility of these structures as fish protection devices. The most alarming aspect is that of all systems, only those at Bonneville have undergone close scrutiny. What harm (or benefit if any) is accruing to fish bypassed at the other dams?

All traveling screen/bypasses have the built-in inherent problem of concentrating fish at the bypass exit (Collins et al. 1975). The foresight of Collins was uncanny in regard to the then-planned Bonneville Dam screening project, as he opined: "However, even at the new Bonneville installation, the bypass system should be evaluated before the screens are installed." The NMFS biologists were recommending that if the bypass portion of the system was unsatisfactory, traveling screens should not be used. This advice went unheeded and so we have fully screened systems and bypasses operating with little or no evaluation. It should be noted that screen evaluations to date have been independent of the bypass evaluations.

Fortunately, bypass systems do not have to be operated in a bypass mode--they can collect fish for transportation. During the early development of traveling screen/bypasses it was a foregone conclusion that the systems would be used solely for transportation. That is the reason systems were developed for Little Goose (uppermost dam at the time), then Lower Granite, and finally at McNary where fish from both the Snake River and mid-Columbia River reaches would be protected.

A major problem associated with the development of traveling screens was that screening was implemented prior to complete evaluation. This was especially true at Little Goose Dam, but applied also at Lower Granite and McNary. I believe there is a very real danger that the new extended bar screens may be installed prematurely at McNary Dam. Test data from 1992 indicates that descaling for spring/summer "chinook was higher (value not given) than for standard length screens (Brege et al. 1992). Funding for the screens is set on a rigid schedule. Therefore; it is likely that screens could be installed during evaluation. Screens should be placed in storage if they are purchased before evaluation is complete.

There is a probable huge but undetermined risk if fish are flushed to the river in concentrations at bypass outfalls. To reduce the risk, listed species should be collected and transported at all dams where facilities exist. Where collection facilities do not exist, consideration should be given to removing screens or, alternatively, modifying the system for collection.

\section{AN ANALYSIS OF TRANSPORTATIONAS AN ALTERNATIVE TO "SPREAD THE RISK"}

The fisheries management agencies have developed a policy of "spread the risk" or "share the risk. "I define "share the risk" as: There are risks in placing fish back in the river and there are risks in transporting all the fish. The reason for the policy is that the agencies perceive that transportation test results are inconclusive; therefore, some fish should be bypassed to enhance their survival prospects and to continue a "natural" 
migration to the sea. The basic elements of the policy include (Anon. 1985):

Lower Granite Dam: All smolts should be transported under all flow conditions.

Little Goose Dam: Fish will be transported only when flow is $100 \mathrm{kcfs}$ or less. When flow exceeds $100 \mathrm{kcfs}$ fish will bypassed to the river.

McNary Dam: Fish will be transported when flow is less than $220 \mathrm{kcfs}$. At flows in excess of $220 \mathrm{kcfs}$, fish are to be bypassed to the river.

Additionally, when the Fish Passage Center estimates that $80 \%$ of the spring/summer chinook have passed Little Goose or McNary, all fish will be transported at those dams to protect steelhead.

The problems with this policy are' three-fold. First, releasing fish (spring/summer chinook) from a collection facility after they have passed through a screen/bypass system to a concentrated area in the tailrace flies in the face of known information on predation at bypass outfalls. Second, screen/ bypass systems are not benign. One needs to ask: Does it make biological sense to release fish at Little Goose Dam with the prospect that the fish will have to negotiate up to six more traumatic bypass systems? Realistically, the only hope for survival may be for the fish to pass through turbines or over the spillway of the remaining six dams. Third, there is no compelling reason why smolts should not be transported under all flow conditions. (The language of the policy implies the agencies fully endorse transportation only under low flow conditions.) The following analysis shows there is a large numerical advantage for transporting smolts when river conditions are optimal compared with catastrophic conditions.

The year 1977 provides a worst-case scenario for poor river conditions (Park et al. 1978). Flows were extremely low and fish arriving at Lower Granite Dam were in poor condition. All smolts that could be collected at Lower Granite and Little Goose were transported (except experiment control fish). It was estimated that survival of all fish not transported was $<1 \%(\mathrm{H}$. Raymond, personal communication). It was estimated that 4,000 spring/ summer chinook salmon returned from this first mass transport effort (Raymond 1988). Many refinements and improvements have been made to transport and collection operations since. It is possible that the expected return now, given similar riverine conditions, might be double or even triple that experienced in 1977.

On the other hand, if transport occurs when riverine conditions are optimum, the results are extremely encouraging. Again, I use 1975 as an example. From Table 7, if only 50\% guidance is achieved, and even if all non-transported fish perish, there is still a net gain of about 4,000 fish--67,000 total returns using full transport at Lower Granite. If FGE can be improved to $80 \%$ without compromising the condition of guided fish, we can make further gains. More fish would be transported to safety below Bonneville Dam and fewer would be passed to dangerous mortality areas downstream from collector dams. 


\section{FUTURE TRANSPORTATIONOPERATIONS}

Smolt transportation can be used effectively to protect listed species with existing facilities and transport equipment. That is not to say there is no room for improvement. In most cases improvements can be made and used in an adaptive way--others may need testing before risking exposure of wild fish.

\subsection{TRANSI'ORT MODE}

Fish transport barges have been tremendously improved since first used in 1977 (McCabe et al. 1979). Barges provide the largest measure of safety for fish. I believe they should be used exclusively, assuming that some wild fish are always present in the population. In the event that a barge is disabled, fish can be released back to the river. Another major advantage is that barges can remove nitrogen and other supersaturated gases from water in the circulation system.

Cooling the water in barge circulation systems has been advocated (NPPC 1992).

This amounts to fixing a system that is not broken. If water is cooled during transport, it must be heated again to avoid thermal shock when the fish are released.

\subsection{MIXED SPECIES TRANSPORT}

The use of "wet separators" at collector dams provides a means of separating large fish (steelhead) from small fish (spring/summer chinook and sockeye) (Park et al. 1982). Separators are now used at Little Goose and McNary Dams. They will be in place in the near future at Lower Granite and Lower Monumental Dams.

During 1983, Park et al. (1984) conducted stress/challenge tests whereby spring/summer chinook were held alone (representing ideal separation), with small ( $<185 \mathrm{~mm}$ ) steelhead (representing practical separation), and with large ( $>185 \mathrm{~mm}$ ) steelhead (representing no separation). The chinook were significantly more stressed when held with either group of steelhead for $14 \mathrm{~h}$ (as in collection awaiting transport) than when kept separated. While the data imply a benefit for separation, the authors concluded from this and other tests, that more testing would be required for conclusive evidence that separation is required.

In lieu of scientific evidence to the contrary, error should be on the side of caution and whenever possible listed species should not be transported with steelhead. The problem may be exacerbated in recent years by presence of many millions of hatchery steelhead, many of which are $>250 \mathrm{~mm}$.

\subsection{LOADING DENSITIES}

Loading densities for barges, trucks, and raceways have been established by the Fisheries Transportation Oversight Team (FTOT). Criteria were established in 1981 
(Basham et al. 1982) and remain the same in 1992. For barges, trucks, and raceways the loading rate is $0.5 \mathrm{lb}$ per gallon. This means that the newer barges $(100,000$ galloncapacity) can carry 50,000 lb of fish (Koski et al. 1990)--more than the entire outmigration of the listed species combined in 1992.

There are times when there are simply too many fish in the collection raceways to transport them in a timely fashion. A simple solution to the problem is to reduce the number of fish being released from hatcheries. Concern was expressed earlier about too many hatchery spring/summer chinook. Steelhead production in hatcheries is also excessive. There are millions more steelhead released now than in the 1970s. During the 1960s there were about 5 million steelhead and spring/ summer chinook combined in the spring outmigration (Raymond 1979). Now that number is approaching 20 million. Is there enough food to support this unnatural abundance of fish on their downstream migration? Is there enough space in collection and transport facilities? These questions must be addressed by those making recovery plans for the listed species.

\section{RESEARCH FOR ENHANCING WILD FISH}

\subsection{RELEASE SITE STUDIES}

Past research has provided an abundance of data indicating that transportation should be used for assisting listed species as a part of the recovery process. However, present transportation activities could be improved. In my view the most critical part of the transportation process now is the transport release site. More tests will be required to determine optimum sites.

Fortunately, we have a head-start to determine better release locations in the lower Columbia River. During 1992, steelhead were marked for comparative releases at the standard Bonneville location (actually several miles below the dam) and at Tongue Point near Astoria, Oregon (Matthews et al. 1992). The data of Solazzi et al. (1991), indicate that survival may be dramatically improved. Even if the steelhead experiment fails, the concept should be pursued at other locations between Bonneville Dam and the mouth of the Columbia River.

For improved release site experiments, steelhead or hatchery spring/summer chinook should be used. Listed species should not be used as too many fish are required for marking.

\subsection{HOMING STUDIES}

If new release sites are used far downriver, homing will necessarily become a part of that evaluation. It is possible that new release sites can be used for all fish based solely on steelhead adult returns. If they are, effects of the extra-long-haul transport on listed species could be evaluated by using PIT tags. PIT tags are already used on wild fish for early life history studies (Matthews et al. 1990). It may be feasible to incorporate these fish into an experimental design for homing because it will be known 
which fish were transported and which were not.

Alternatively, homing studies could be undertaken using only hatchery fish. Again, PIT tags could be used but more tags would be required because hatchery fish survival is so low. In either case, homing studies should be planned for the near future.

\subsection{HATCHERY FISH FOR RESEARCH}

Hatchery fish should be used for research, not only in transportation studies but other disciplines where study is needed. I emphasize, hatchery fish should be used for research in lieu of, rather than in addition to, production releases. Production releases such as occurred in the last decade are not needed and are likely counterproductive toward rebuilding listed wild fish. Hatchery fish are not ideal for test animals because of their dubious survival qualities; however, there is little choice since research will be required while wild fish are in short supply. 


\section{LITERATURE CITED}

Anderson, D. A. and W. E. McConnaha. 1992. Effect of 1992-93 operations on spring chinook salmon in the Snake River. In: Draft Interim Columbia and Snake Rivers flow improvement measures for salmon draft supplemental environmental impact statement. USACE, Walla Walla, WA. 24 p.

Anonymous. 1985. The Fish Transportation Oversight Team annual work plan for transport operations at Lower Granite, Little Goose and McNary Dams for the field year 1984. Unpublished document.

Banner, C. R., J. S. Rohovec, and J. L. Fryer. 1982.

Renibacterium salmoninarum as a cause of mortality among chinook salmon in saltwater. Proceedings of the 14th annual meeting of the World Mariculture, Society. 236-239 p.

Basham, L. R., M. R. Delarm, J. B. Atheam, and J. V. Barker. 1982. Fish transportation oversight team annual report-FY 1981. NOAA Technical Memorandum NMFS F/NWR-2. Portland, OR.

Borgerson, L. A. 1992. Life history studies of spring and summer chinook salmon and steelhead from the Snake River using scale analysis. In: USACE Fish passage development and evaluation program 1992 annual program review. Portland, OR.

Brege, D. A., R. L. McComas, W. D. Muir, B. P. Sanford, and D. B.

Dey. 1992. Studies to determine the effectiveness of extended submersible bar screens at McNary Dam, 1992. In: USACE Fish Passage Development and Evaluation Program 1992 Annual Program Review. Portland, OR.

Carlson, C. D. and G. M. Matthews. 1992. Fish transportation studies Priest Rapids Dam 1991. Public Utility District No. 2 of Grant County, Ephrata, WA. 7 p. plus Appendix.

Carlson, C. D. and G. M. Matthews. 1991. Salmon transportation studies--Priest Rapids Dam, 1990. Public Utility District No. 2 of Grant County, Ephrata, WA. 9 p. plus Appendix.

Carlson, C. D. and G. M. Matthews. 1991. Fish transportation studies Priest Rapids Dam 1989. Public Utility District No. 2 of Grant County, Ephrata, WA. 7 p. plus Appendix. 
Carlson, C. D., G. M. Matthews, D. E. Weitkamp, R. P. Whitman, R.

Raleigh, D. Chapman. 1989. Fish transportation studies Priest Rapids

Dam 1988. Public Utility District No. 2 of Grant County, Ephrata, WA. 26 p. plus Appendix.

Carlson, C. D., S. Achord, G. M. Matthews, D. E. Weitkamp, R. P.

Whitman, R. Raleigh, and D. Chapman. 1988. Fish transportation studies Priest Rapids Dam 1987. Public Utility District No 2 of Grant County, Ephrata, WA. 33 p. plus Appendix.

Ceballos, J. R., S. W. Pettit, and J. L. McKern. 1991. Fish transportation oversight team annual report-FY 1990 transport operations in the Snake and Columbia Rivers. NOAA Technical Memorandum NMFS F/NWR-29. 75 p. plus Appendix.

Chapman, D. W., A. Giorgi, M. Hill, A. Maule, S. McCutcheon, D. Park, W. PJatts, K. Pratt, J. Seeb, L. Seeb, and F. Utter. 1991. Status of Snake River chinook salmon. Pacific Northwest Utility Conference Committee. Portland, OR.

Collins, G. B., W. J. Ebel, G. E. Monan, H. L. Raymond, and G. K. Tanonaka. 1975. The Snake River salmon and steelhead crisis--its relation to dams and the national energy crisis. Processed report. NOAA, NMFS, 2725 Montlake Blvd. E., Seattle, WA. 30 p.

Dawley. E. M., L. G. Gilbreath, and R. D. Ledgerwood. 1992.

Relative survival of subyearling chinook salmon that have passed Bonneville Dam via the first powerhouse turbines or bypass and tailrace or second powerhouse turbines and tailrace in 1992. In: Corps of Engineers Fish Passage Development and Evaluation Program 1992 Annual Review, Portland, OR.

Ebel, W. J. 1980. Transportation of chinook salmon, Oncorhvnchus Tshawvtscha, and steelhead, Salmo gairdneri, smolts in the Columbia River and effects on adult returns. USFWS, Fisheries Bulletin. 78(2):491-505.

Ebel, W. J., D. L. Park, and R. C. Johnsen. 1973. Effects of transportation on survival and homing of Snake River chinook salmon and steelhead trout. U.S. Fish and Wildlife Service. Fisheries Bulletin 7 1: 549563.

Ebel, W. J. 1970. Effect of release location on survival of juvenile fall chinook salmon, Oncorhvnchus tshauntscha. Transactions 
American Fisheries Society. 99(4):672-676.

Elliott, D. G. and R. J. Pascho. 1992. Juvenile fish transportation: Impact of bacterial kidney disease on survival of spring/summer chinook stocks. Annual report-1990. USFWS, NFRC, Seattle, WA. 92 p. plus Appendix.

Giorgi, A. 1991. Mortality of yearling chinook salmon prior to arrival at Lower Granite Dam on the Snake River. BPA Research Report. Don Chapman Consultants, Inc. 26 p.

Giorgi, A. E., G. A. Swan, and W. S. Zaugg. 1988.

Susceptibility of chinook salmon smolts to bypass systems at hydroelectric dams. North American Journal of Fisheries Management. 8:25-29.

Harmon, J. R., and E. Slatick. 1986. Use of a fish transportatipn barge for increasing returns of steelhead imprinted for homing. Annual report of research (BPA), NOAA, NMFS, 2725 Montlake Blvd. E., Seattle, WA. 21 p. plus Appendix.

Koski, C. H., S. W. Pettit, and J. L. McKern. 1990. Transport operations on the Snake and Columbia Rivers. Fish Transport Oversight Team Annual Report - FY 1989. NOAA Technical Memorandum. NMFS/NWR-27.

Ledgerwood, R. D., E. M. Dawley, L. G. Gilbreath, P. J. Bentley, B. Sanford, and M. H. Schiewe. 1990. Relative survival of subyearling chinook salmon which have passed Bonneville Dam via the spillway or the second powerhouse turbines or bypass system in 1989, with comparisons to 1987 and 1988. USACE Annual Report of Research. NOAA, NMFS, 2725 Montlake Blvd. E., Seattle, WA.

McCabe, G. T., C. W. Long, and D. L. Park. 1979. Barge transportation of juvenile salmonids on the Columbia and Snake Rivers. 1977. Marine Fisheries Review. July 1979:28-34.

Matthews, G. M. 1992. Potential of short-haul barging as a bypass release strategy. Processed report. National Marine Fisheries Service, NWFSC, 2725 Montlake Boulevard E., Seattle, WA. 98112.

Matthews, G. M., J. R. Harmon, B. P. Sandford, N. N. Paasch, K.

L. Thomas, and K. W. McIntyre. 1992. Evaluation of improved collection, handling, and transport techniques to increase survival of juvenile salmonids, 1992. In: Corps of Engineers fish passage development and 
evaluation program, 1992 annual program review. Portland, OR.

Matthews, G. M. and R. S. Waples. 1991. Status review for Snake

River spring and summer chinook salmon. NOAA Technical

Memorandum NMFS F/NWC-200. NOAA, NMFS, NWFC, 2725

Montlake Blvd. E., Seattle, WA. 75 p.

Matthews, G. M., J. R. Harmon, S. Achord, 0. W. Johnson, and

Leslie Kubin. 1990. Evaluation of transportation of juvenile salmonids and related research on the Columbia and Snake Rivers, 1989. NOAA, NMFS, NWFSC, 2725 Montlake Blvd. E., Seattle, WA. 98112. 59 p. plus Appendix.

Matthews, G. M., D. L. Park, J. R. Harmon, and T. E. Ruehle. 1988. Evaluation of transportation. of juvenile salmonids and related research on the Columbia and Snake Rivers, 1987. Report to U. S. Army Corps of Engineers, Contract DACW68-84-H0034, 25 p. plus Appendix. Northwest Fisheries Center, 2725 Montlake Blvd. E., Seattle, WA

Matthews, G. M., D. L. Park, J. R. Harmon, C. S. McCutcheon, and A. J. Novotny. 1987. Evaluation of transportation of juvenile salmonids and related research on the Columbia and Snake rivers 1986. NOAA, NMFS, 2725 Montlake Blvd E., Seattle, WA.

Matthews, G. M., D. L. Park, S. Achord, and T. E. Ruehle. 1986. Static seawater challenge test to measure relative stress levels in spring chinook salmon smolts. Transactions American Fisheries Society. 115(2):236-244.

Matthews, G. M., G. A. Swan, and J. R. Smith. 1977. Improved bypass and collection system for protection of juvenile salmon and steelhead trout at Lower Granite Dam. Marine Fisheries Review 47(7):2834.

McConnaha, W. E. 1991. A conceptual model of smolt transportation in the Columbia River. Northwest Power Planning Council, Portland, OR. 6 p.

Nickelson, T. E. 1986. Influences of upwelling, ocean temperature, and smolt abundance on marine survival of coho salmon (Oncorhynchus kisutch) in the Oregon production area. Canadian Journal of Fisheries and Aquatic Sciences. 45:1366-1377. 
NPPC. 1992. Strategy for salmon. Northwest Power Planning Council, Portland, OR. Publication No. 92-20. 43 p.

Park, D. L. 1985. A review of smolt transportation to bypass dams on the Snake and Columbia Rivers. U. S. Army Corps of Engineers, Walla Walla, WA.

Park, D. L., G. M. Matthews, J. R. Smith, T. E. Ruehle, J. R. Harmon, and S. Achord. 1984. Evaluation of transportation of juvenile salmonids and related research on the Columbia and Snake Rivers, 1983. USACE Annual Research Report. NOAA, NMFS, 2725 Montlake Blvd E., Seattle, WA. 39 p. plus Appendix.

Park, D. L., J. R. Smith, G. M. Matthews, T. E. Ruehle, T. W. Newcomb, L. R. Basham, and T. A. Flagg. 1982. Transportation operations and related research on the Columbia and Snake Rivers, 1981. NOAA, NMFS, NWAFC, 2725 Montlake Blvd. E., Seattle, WA. 32 p. plus Appendix.

Park, D. L., J. R. Harmon, B. H. Monk, T. E. Ruehle, T. W. Newcomb, L. R. Basham, and T. A. Flagg. 1981. Transportation research on the Columbia and Snake Rivers, 1980. NOAA, NWAFC, NMFS, Seattle, WA. 32 p. plus Appendix.

Park, D. L., J. R. Smith, G. M. Matthews, L. R. Basham, G. A. Swan, G. T. McCabe, T. R. Ruehle, J. R. Harmon, and B. H. Monk. 1979. Transportation research on the Columbia and Snake Rivers, 1978. NOAA, NMFS, NWAFC, Seattle, WA. 65 p. plus Appendix.

Park, D. L., J. R. Smith, E. Slatick, G. M. Matthews, L. R, Basham, and G. A. Swan. 1978. Evaluation of fish protective facilities at Little Goose and Lower Granite Dams and review of mass transportation activities, 1977. USACE Annual Research Report. NOAA, NMFS, 2725 Montlake Blvd. E., Seattle, WA. 51 p. plus Appendix.

Park, D. L., J. R. Smith, E. Slatick, G. A. Swan, E. M. Dawley, and G. M. Matthews. 1977. Evaluation of fish protective facilities at Little Goose and Lower Granite Dams and review of nitrogen studies relating to protection of juvenile salmonids in the Columbia and Snake Rivers, 1976. NOAA, NMFS, NWAFC, Seattle, WA. 47 p. plus Appendix.

Park, D. L., E. M. Dawley, R. F. Krcma, C. W. Long, E. Slatick, J. R. Smith, and G. A. Swan. 1976. Evaluation of fish protective facilities at Little Goose and Lower Granite Dams, and review of other studies 
relating to protection of juvenile salmonids in the Columbia and Snake Rivers, 1975. NOAA, NWAFC, NMFS, Seattle, WA. 50 p. plus Appendix.

Pascho, R. J. and D. G. Elliott. 1989. Juvenile fish transportation: impact of bacterial kidney disease on survival of spring/summer chinook stocks. Annual report of research 1988. USFWS, NFRC, Seattle, WA.

Raymond, H. L. 1988. Effects of hydroelectric development and fisheries enhancement on spring and summer chinook salmon and steelhead in the Columbia River Basin. North American Journal of Fisheries Management. 8(1): 1-23.

Raymond, H. L. 1979. Effects of dams and impoundments on migrations of juvenile chinook salmon and steelhead from the Snake River, 1966-1975. Transactions American Fisheries Society 108:505-529.

Solazzi, M. F, T. E. Nichelson, and S. L. Johnson. 1991.

Survival, contribution, and return of hatchery coho salmon (Oncorhynchus kisutch) released into freshwater, estuarine, and marine environments. Canadian Journal of Fisheries and Aquatic Sciences 48:248-253.

Vreeland, R., and R. Wahle. 1983. Homing and fisheries contribution of marked coho salmon, Oncorhvnchus kisutch, released at two Columbia River Locations. Fishery Bulletin: Vol 81(1)143.

Wedemeyer, G. A., A. N. Palmisano, and L. E. Salsbury. 1985.

Development of an effective transport media for juvenile spring chinook salmon to mitigate stress and improve smolt survival during Columbia River fish hauling operations. USFWS, NFRC, Seattle, WA. 